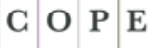

\title{
Qualitative Inquiry into Art History: A Tribute to Arthur P. Bochner ${ }^{1}$
}

\author{
In 1988, an intense, \\ driven department chair, \\ respected scholar, \\ and prolific author \\ lost suddenly, \\ unexpectedly, \\ his aging but vital father, \\ and became, as never before, \\ a wounded storyteller. ${ }^{2}$
"It's About Time,"3
he came to believe, to integrate fractured identities divided by academic pursuit and personal grief.

\footnotetext{
* Department of Critical Media \& Cultural Studies Rollins College.

${ }^{1}$ This work was originally published as: L. M. Tillmann-Healy (2004) Qualitative Inquiry into Art History: A Tribute to Arthur P. Bochner, "American Communication Journal," 7. Reprinted by permission of the American Communication Association.

${ }^{2}$ Frank (1995).

${ }^{3}$ Bochner (1997).
} 


\section{Self-transformation}

became a social construction

when sociology's path

crossed that of communication.

Who was this vision, on a mission,

firing a new canon

that would become Final Negotiations? ${ }^{4}$

Companion became partner and sometime thereafter,

an impulse artfully paternal sparked in the heart Art Bochner.

To be counted among the adopted is not without responsibility.

For me it meant assistantships

on family dynamics

and cinematic relationships, and a five-course meal of Interpretivism, Narrative Methodology, Close Relationships, Writing Workshop, and Communication Theory.

A class called Interpretivism,

Fall, 1993,

began with Mead's Mind, Self, \& Society. ${ }^{5}$

M.A.s and Ph.D.s to be

emplotted our "I"s and tossed our "me"s

into a sea

of essential We.

In a hermeneutic circle

we engaged Interaction Ritual ${ }^{6}$

until teeming

with finite provinces ${ }^{7}$

and Acts of Meaning. ${ }^{8}$

\footnotetext{
${ }^{4}$ Ellis (1995).

${ }^{5}$ Mead (1967).

${ }^{6}$ Goffman (1982).

${ }^{7}$ Berger, Luckmann (1989).

${ }^{8}$ Bruner (1990).
} 
For Narrative Inquiry,

we heard The Call of Stories. ${ }^{9}$

Through border-crossing life histories, we faced abuse, divorce, cancer, AIDS, their-and our-mortality,

at times unbearable reflexivity, the "gift" lost in the chaos of calamity.

And so we wrote.

We wrote of resilience born of fragility,

of stumbling toward imperfect mutuality.

These projects-these life projects-

moved through uncertainty

and ineffability,

$$
\begin{aligned}
& \text { toward epiphany, } \\
& \text { not a recovery }
\end{aligned}
$$

of whom we had been

but of a rhetoric of possibility

of whom we might become.

Our narrative challenge: to co-author stories

that could be both told

and lived.

\section{Communication in Close Relationships}

offered homeostasis in Batesonian cybernetics, ${ }^{10}$

but tension in Rawlinsonian dialectics. ${ }^{11}$

Only 15 weeks, but several Pathways to Madness. ${ }^{12}$

We were a wreck through Denial of Death, ${ }^{13}$

gloom oozing into our attitudes

when Becker's terrors of finitude

wrought too much verisimilitude.

Lest other illusions

Cause confusion,

we saw the backward nature of Betrayal, ${ }^{14}$

and Scenes from a Marriage ${ }^{15}$ we all hated.

${ }^{9}$ Coles (1989).

${ }^{10}$ Bateson (1972).

11 Rawlins (1992).

12 Henry (1973).

13 Becker (1973).

14 Spiegel, Jones (1983).

15 Carlberg, Bergman (1973). 
For Writing Workshop,

we learned to pen an Art-ful social science.

With self-consciousness and interhuman presence, we dizzily spun webs of significance, ${ }^{16}$ moving from silence to utterance to transcendence and performance.

In Communication Theory, we gained many "Perspectives on Inquiry"17,18 and forayed into

the interdisciplinary phenomenology of Arthur ideology.

Students were infused

with systems and critical theories, pragmatist ontologies, constructivist epistemologies, and interpretivist methodologies.

Enter intersubjectivity, the selectivity of memory, Shweder's "Divergent Rationalities,"19 language's exuberences and deficiencies, ${ }^{20}$ and Roshomon' ${ }^{21}$ multiple realities.

Said Doctor Bochner,

"Choose your conversation partners carefully;

some of them will drive you crazy."

we went "Mucking Around Looking for Truth."22

In search of proof,

"But how do you know?" we asked King Arthur.

"I'm not positivist," was his rejoinder,

"but I promise to tell a truth,

a local truth,

an evocative narrative truth, so help me Coles. ${ }^{23}$

\footnotetext{
${ }^{16}$ Geertz (1973).

${ }^{17}$ Bochner (1985).

${ }^{18}$ Bochner (1994).

${ }^{19}$ Shweder (1986).

${ }^{20}$ Becker (1991).

21 Jingo, Kurosawa (1950).

${ }^{22}$ Bochner, Ellis, Tillmann-Healy (1998).

${ }^{23}$ Coles (1989).
} 
And let's forgo how I know.

Ask instead

the name and frame of this language game,

the subtext of this context,

the pattern of this symbolic interaction-

in other words: why I talk this way."

To explore this lead, we took in his writing.

Ethnographically Speaking, ${ }^{24}$

he connected "Telling and Living." 25

Art sparked

"Representation, Conversation and Reflection,"26

offered a vulnerable observation

of institutional depression, ${ }^{27}$

helped us sense and feel

"The Constraints of Choice in Abortion."28

"Theories and Stories," 29

"Autoethnography, Personal Narrative, Reflexivity,"31

"Relationships as Stories,"30

and Composing Ethnography ${ }^{32}$

contested the politics of neutrality,

offering instead the certainty of contingency,

and clarity of irony,

enclosing us warmly

in a therapeutic double bind of hope and empathy.

"The author is dead,"

Michel Foucault had said.

But Arthur lives-and tells.

Arthur P. Bochner:

social science spinner,

literature weaver,

${ }^{24}$ Bochner, Ellis (2002).

25 Bochner, Ellis (1995).

${ }^{26}$ Bochner (1985).

${ }^{27}$ Bochner (1997).

${ }^{28}$ Ellis, Bochner (1992).

${ }^{29}$ Bochner (1994).

${ }^{30}$ Bochner, Ellis, Tillmann-Healy (2000).

31 Bochner, Ellis (2000).

32 Bochner, Ellis (1996). 


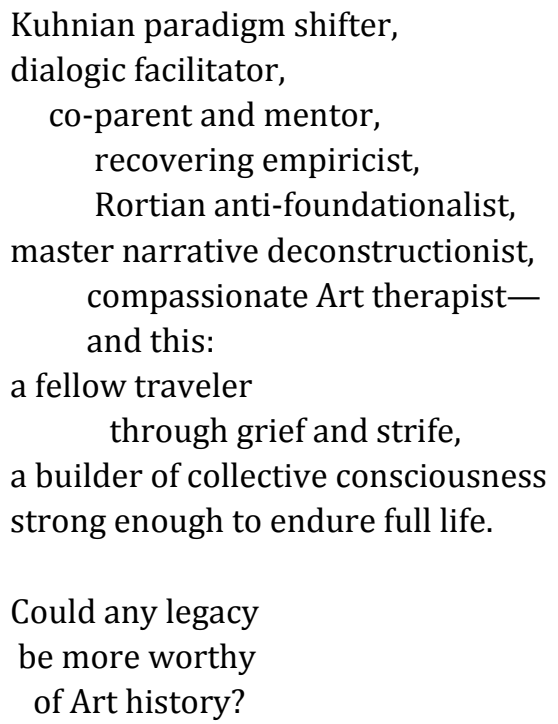

\section{References}

Bateson G. (1972) Steps to an Ecology of Mind: Collected Essays in Anthropology, Psychiatry, Evolution, and Epistemology, New York, Ballantine Books.

Becker A. L. (1991) A Short Essay on Languaging in: Research and Reflexivity, F. Steier (Ed.), Newbury Park, CA, Sage: 226-234.

Becker E. (1973) The Denial of Death, New York, The Free Press.

Berger P. L., Luckmann T. (1989) The Social Construction of Reality: A Treatise in the Sociology of Knowledge, New York, Anchor Books.

Bochner A. P. (1985) Perspectives on Inquiry: Representation, Conversation, and Reflection in: Handbook of Interpersonal Communication, M. L. Knapp, G. R. Miller (Eds.), Newbury Park, CA, Sage: 27-58.

Bochner A. P. (1994) Perspectives on Inquiry II: Theories and Stories in: Handbook of Interpersonal Communication ( $2^{\text {nd }}$ ed.), M. L. Knapp, G. R. Miller (Eds.), Thousand Oaks, CA, Sage: 21-41.

Bochner A. P. (1997) It's About Time: Narrative and the Divided Self, "Qualitative Inquiry," 3. 418-438. 
Bochner A. P., Ellis C. (1995) Telling and Living: Narrative Co-construction and the Practices of Interpersonal Relationships in: Social Approaches to Communication, W. Leeds-Hurwitz (Ed.), New York, Guilford Publications: 201-213.

Bochner A. P., Ellis C. (2000) Autoethnography, Personal Narrative, Reflexivity: Researcher as Subject in: Handbook of Qualitative Research (2nd Ed.), N. K. Denzin, Y. S. Lincoln (Eds.), Thousand Oaks, CA, Sage: 733-768.

Bochner A. P., Ellis C. (Eds.) (1996) Composing Ethnography: Alternative Forms of Qualitative Writing, Walnut Creek, CA, AltaMira Press.

Bochner A. P., \& Ellis C. (Eds.) (2002) Ethnographically Speaking: Autoethnography, Literature, and Aesthetics, Walnut Creek, CA, AltaMira Press.

Bochner A. P., Ellis C. Tillmann-Healy L. (1998) Mucking Around Looking for Truth in: Dialectical Approaches to Studying Interpersonal Relationships, B. M. Montgomery, L. A. Baxter (Eds.), Mahwah, NJ, Lawrence Erlbaum: 41-62.

Bochner A. P., Ellis C., Tillmann-Healy L. M. (2000) Relationships as Stories: Accounts, Storied Lives, Evocative Narratives in: Communication and Personal Relationships, K. Dindia, S. Duck (Eds.), Chichester, John Wiley \& Sons, Ltd.: 12-29.

Bruner J. (1990) Acts of Meaning, Cambridge, MA, Harvard University Press.

Carlberg L. O. (producer), Bergman I. (director) (1973) Scenes from a Marriage [motion picture], Sweden, Cinema 5 Distribution.

Coles R. (1989) The Call of Stories: Teaching and the Moral Imagination, Boston, Houghton Mifflin.

Ellis C. (1995) Final Negotiations: A Story of Love, Loss, and Chronic Illness, Philadelphia, Temple University Press.

Ellis C., Bochner A. P. (1992) Telling and Performing Personal Stories: The Constraints of Choice in Abortion in: Investigating Subjectivity: Research on Lived Experience, C. Ellis, M. J. Flaherty (Eds.), Newbury Park, CA, Sage: 79-101.

Frank A. W. (1995) The Wounded Storyteller: Body, Illness, and Ethics, Chicago, University of Chicago Press.

Geertz C. (1973) The Interpretation of Cultures, New York, Basic Books.

Goffman E. (1982) Interaction Ritual: Essays on Face-to-Face Behavior, New York, Pantheon Books. 
Henry J. (1973) Pathways to Madness, New York, Vintage Books.

Jingo M. (producer), Kurosawa A. (director) (1950) Roshomon [motion picture], Japan, Daiei Film.

Mead G. H. (1967) Mind, Self, \& Society, Chicago, The University of Chicago Press.

Rawlins W. K. (1992). Friendship Matters: Communication, Dialectics, and the Life Course, New York, Aldine de Gruyter.

Shweder R. A. (1986) Divergent Rationalities in: Metatheory in Social Science: Pluralisms and Subjectivities, D. W. Fiske, R. A. Shweder (Eds.), Chicago, University of Chicago Press: 163-196.

Spiegel S. (producer), Jones D. (director) (1983) Betrayal [motion picture] United States, 20th Century Fox. 